\title{
Process and outcome in communication of genetic information within families: a systematic review
}

\author{
Clara L Gaff*,1, Angus J Clarke ${ }^{1}$, Paul Atkinson ${ }^{2}$, Stephanie Sivell ${ }^{3}$, Glyn Elwyn ${ }^{3}$, \\ Rachel Iredale $^{1}$, Hazel Thornton ${ }^{4}$, Joanna Dundon ${ }^{5}$, Chris Shaw ${ }^{3}$ and Adrian Edwards ${ }^{3}$
}

\begin{abstract}
${ }^{1}$ Institute of Medical Genetics, Cardiff University, Cardiff, UK; ${ }^{2}$ Centre for Economic and Social Aspects of Genetics (CESAGEN), School of Social Sciences, Cardiff University, Cardiff, UK; ${ }^{3}$ Department of Primary Care and Public Health, Centre for Health Sciences Research, Cardiff University, Cardiff, UK; ${ }^{4}$ Department of Health Sciences, University of Leicester, Leicester, UK; ${ }^{5}$ Gwent Healthcare NHS Trust, Torfaen, UK
\end{abstract}

The communication of risk is a central activity in clinical genetics, with genetic health professionals encouraging the dissemination of relevant information by individuals to their at-risk family members. To understand the process by which communication occurs as well as its outcomes, a systematic review of actual communication in families about genetic risk was conducted. Findings from 29 papers meeting the inclusion criteria were summarised and are presented narratively. Family communication about genetic risk is described as a deliberative process, in which: sense is made of personal risk; the vulnerability and receptivity of the family member is assessed; decisions are made about what will be conveyed; and the right time to disclose is selected. The communication strategy adopted will depend on these factors and varies within families as well as between families. Inherent in these processes are conflicting senses of responsibility: to provide potentially valuable information and to prevent harm that may arise from this knowledge. However, the research 'outcomes' of communication have been professionally determined (number of relatives reported as informed, uptake of testing, knowledge of the recipient) and are typically unrelated to the concerns of the family member. The impact of communication on the individual, family members, and family relationships is of concern to the individual conveying the information, but this is largely self-reported. Currently, there is insufficient information to inform the development of theoretically and empirically based practice to foster 'good' communication. The implications for future research are discussed.

European Journal of Human Genetics (2007) 15, 999-1011; doi:10.1038/sj.ejhg.5201883; published online 4 July 2007

Keywords: family; communication; genetic counselling; genetic predisposition to disease; risk

\section{Introduction}

The ethos of clinical genetics is to consider the risks of a genetic condition not only for the consultand attending the genetics clinic but also to relatives of that person. ${ }^{1}$ The

*Correspondence: Dr CL Gaff, Genetic Health Services Victoria, 10th Floor, Royal Children's Hospital, Flemington Rd, Parkville VIC 3052, Australia. Tel: +61 (0) 8341 6201; Fax: + 61 (0) 8341 6390;

E-mail: clara.gaff@ghsv.org.au

Received 20 March 2007; revised 22 May 2007; accepted 29 May 2007; published online 4 July 2007 extent to which the genetic specialist should shoulder the responsibility for ensuring that family members are aware of their risk is a perennial debate in genetics. In contrast to infectious diseases, communication of genetic risk to those considered at risk is 'ethically dubious' in nature, with a lack of clarity about what individuals should reasonably be expected to do, and how professionals should respond when they are aware that communication within a family has failed or is blocked. This will depend in part on the nature of the information available (risk information only or genetic test results) and implications of the condition. 
For instance, a greater imperative may be felt when preventive treatment options or reproductive choices are being restricted. In general, there seems to be an uneasy consensus that genetic services should rely predominantly on the consultand to convey information, except in exceptional circumstances. ${ }^{2}$

The consultand, however, does not always convey risk information to their at-risk family members. First-degree relatives are consistently given genetic risk information directly by the proband more frequently than the secondand the third-degree relatives. Wilson et $\mathrm{al}^{3}$ have comprehensively reviewed the complex factors influencing whether information about genetic risk is shared with family members, describing individual and family characteristics, disease, and sociocultural factors that can affect this process. It has been suggested that disclosure of genetic information is best described as a process rather than an act, ${ }^{4}$ implying a collection of actions rather than a single event. If genetics professionals are to continue to rely on family members to convey information - or, conversely, if they seek greater participation in this process - it is important to extend beyond identifying the factors that influence who in the family will be informed and gain an understanding of the process of communication of genetic information within families and its consequences. We conducted a systematic review of papers to illuminate these aspects of communication, with the intention of informing future practice in the facilitation of communication within families by health professionals.

\section{Methods}

\section{Search strategy}

Six electronic databases (Medline, CINAHL, Cochrane Library, EMBASE, PsycInfo, and National Research Register) were searched from 1985 to January 2006. The search strategy was broad (high recall and low precision), as this review was part of a wider review of risk communication in genetics. ${ }^{5}$ Searches focussed on risk and communication; genetics, predisposition, screening, or counselling; and service delivery, health services, and organisation. The strategy used for Medline is shown in the Supplementary Material. Follow-up searches included both electronic (Citation Indices) and manual searches (key authors encountered most frequently in the field and reference lists of included papers).

\section{Assessment for inclusion of studies}

The inclusion criteria were peer-reviewed publications on the process and outcome of communication of genetic risk to family members. Communication related only to actual discourse, dissemination, or behaviours with case reports, hypothetical, or anticipated communication excluded. Genetic risk included information about the condition, numeric risk, or genetic test results. All papers meeting these criteria and utilising qualitative methods were included; quantitative data were only included if it specifically provided information on outcomes of communication. Two reviewers assessed all titles and abstracts and examined full-copy papers of potentially relevant references. Decisions were made independently about inclusion or exclusion, with reference to a third reviewer if there was disagreement between the first two.

\section{Data extraction and analysis}

Papers identified as containing information about communication of risk were read in detail by two investigators (CL Gaff and AJ Clarke). An aggregative synthesis approach, focussing on summarising data, was adopted. ${ }^{6}$ Relevant findings were coded on data extraction templates in an Access database and are presented in narrative form. Multiple papers from a single study have been extracted and presented as a single study.

\section{Results}

Twenty-nine papers from 26 studies were subjected to data extraction. Figure 1 illustrates the search results and a summary of relevant findings is presented in the Supplementary Material. While this review focusses on the communication of risk information, none of the papers included describe the content communication in these terms. Nineteen studies discussed transmission of test results, while the remainder were about the diagnosis or genetic condition or were not specific about what was communicated. The majority of papers $(n=21)$ investigate families with hereditary cancer syndromes, with very few on more 'traditional' Mendelian genetic conditions such as Huntington disease (HD) $(n=3)$ or cystic fibrosis (CF) $(n=3)$ or chromosome anomalies $(n=1)$.

Three themes relating to the review topic emerged from analysis of the data: deliberation before communication, communication strategies, and outcomes of communication (Table 1).

\section{Deliberation before communication}

If an individual does not 'immediately' communicate information about genetic risk to their relatives, it appears that they undergo a period of deliberation in which decisions about disclosure are made. Hamilton et $\mathrm{al}^{7}$ describe these deliberations as encompassing (1) consideration of the effects of disclosure, (2) selection of what information to disclose, and (3) planning the timing of disclosure. Forrest et $a l^{4}$ describe an additional phase of 'making sense of personal risk' before being able to deal with deciding who to tell and what to say, with those who continue to perceive their risk as uncertain or ambiguous most likely to have problems knowing what message to give their relatives. However, the ways in which individuals construct and make sense of their risk is beyond the scope 


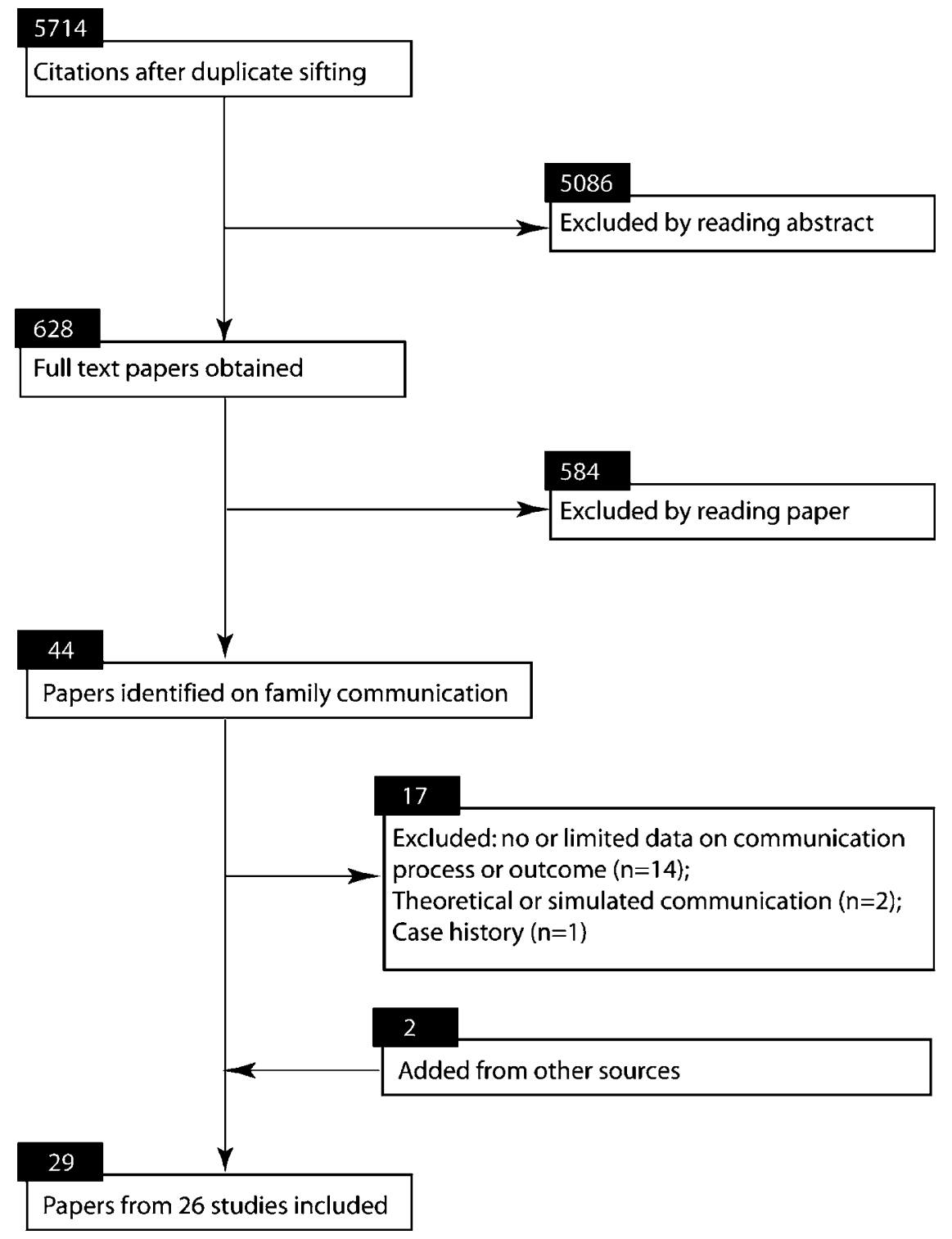

Figure 1 Search results.

of this paper and are presented elsewhere. ${ }^{5}$ The remaining three aspects are discussed here in more detail.

Considering the effects of disclosure Underlying accounts of the decision whether or not to disclose risk information to relatives is a dilemma: the desire to protect relatives from potential harm is weighed against the wish to provide them with information that may have important health consequences. ${ }^{4,8,9}$ In weighing these conflicting responsibilities, the individual assesses their family members' vulnerability to the information as well as their receptivity. ${ }^{7}$ Vulnerability is assessed by considering life circumstances and mental and/or physical condition, as well as the potential harm that may be caused by news that may be perceived as bad or harmful and able to cause upset or worry. ${ }^{4,8,10-16}$ Receptivity is assessed by predicting the response of the family member to the information (see Outcomes of communication).

Selecting what to disclose Individuals can be selective about what information they disclose. In one study, individuals disclosing their HD test results only provided more information if asked to do so, while those from families with hereditary breast ovarian cancer (HBOC) were more forthcoming. ${ }^{7}$ In contrast, some men undergoing testing for HBOC mutations disclosed only limited information about testing and its implications to their children. ${ }^{16}$ Sometimes, selectively conveying information 
may delineate what constitutes 'family information' (ie news of a mutation in the family) and what is 'personal' (individual predictive test results). ${ }^{17}$

Timing of disclosure Disclosing at the 'right time' is of concern to informants. $4,7,14,18,19$ Generally, communication with close relatives happens within a week and late disclosure is less common. ${ }^{12,17,19-22}$ Forrest et al ${ }^{4}$ distinguish pragmatism, where an active approach (such as arranging an appointment or mailing letters) is adopted and prevarication, where the right opportunity is sought. The right 'time' appears to refer to both life stage, for example, availability of surveillance for cancer, forthcoming marriage, or children, and to the right opportunity, for example during normal social contact. ${ }^{4}$ It may also depend on the perceived emotional readiness of the recipient. ${ }^{7}$ It should be noted that communication of results in families with hereditary bowel cancer occurred as part of normal social interaction, but this appeared to be due to a more matter-of-fact approach to hereditary nonpolyposis colorectal cancer (HNPCC) rather than prevarication. ${ }^{17,20}$

\section{Communication strategies}

In some cases, the outcome of the deliberative process will be to decide that the information is not disclosed. Information may be deliberately withheld or kept totally secret. ${ }^{23}$ Alternatively, there may be a 'passive' failure to inform due to poor or nonexistent communication pathways and a low sense of responsibility to that individual. $^{20,24}$ Even when communication does occur, it may not be completely open. Hallowell et $a l^{18}$ describes the different strategies observed in men undergoing testing for HBOC: complete openness, where children were informed about testing at the outset and were one of the first to hear of their father's results; limited disclosure, a cautious approach in which involvement in testing was deliberately downplayed; and total secrecy. Kenen et $\mathrm{al}^{23}$ focus on the interaction between informant and recipient. As before, open and supportive communication is observed. Blocked communication was reported with recipients refusing to receive the information directly (eg hanging up telephone) or indirectly (apparent discomfort, lack of responsiveness, or failure to disclose information themselves). Aspects of selective disclosure were described in this study as 'selfcensoring', with the informant not pursuing difficult conversations or seeking to protect other family members by only giving them reassuring information. Finally, some women used intermediaries if they felt uncomfortable contacting a particular person. These different patterns were observed within families as well as between families.

The use of intermediaries is observed particularly in relation to parents seen as having the responsibility to inform their children (generational responsibility or vertical transmission). ${ }^{4,17,20,25}$ Thus, an individual may directly inform their siblings but would (perhaps implicitly) expect those siblings to inform their own offspring. A cascading of responsibility is apparent, with responsibility for informing others transmitted along with the information conveyed. The assumption that at-risk family members have been informed by other relatives ${ }^{11,15}$ is not necessarily borne out, parents do not always inform adult children ${ }^{21,25,26}$ and children under 18 years of age are less likely to be told. ${ }^{10,18,21,27}$ Intermediaries are recruited to inform other relatives, ${ }^{9,14,24,28}$ particularly by men. ${ }^{14,20}$ This appears to be a different concept to that of a 'pivotal' person who perceives him/herself to take responsibility for passing on the information and encourages relatives to consider testing. ${ }^{17,29,30}$

\section{Outcomes of communication}

An obvious outcome of communication is the reported number of family members informed, but others are also apparent in the literature, namely: uptake of genetic testing, knowledge of the recipient, and family responses to the informant.

Uptake of genetic testing Seven studies investigated uptake of genetic testing by informed relatives. ${ }^{11,15,17,25,28,31,32}$ Most of these studies determined uptake in relatives informed about testing: the percentage of those informed who underwent testing ranged from $13 \%{ }^{32}$ to $57-64 \% .{ }^{17}$ Peterson et al ${ }^{17}$ found somewhat lower uptake of predictive testing for HNPCC (46\%) in a family where disclosure had been delayed compared to families were there had not been a delay (57-64\% uptake). Blandy et $a l^{28}$ found that second- and third-degree relatives, when aware of the mutation, are less likely to proceed with testing than first-degree relatives and also suggested associations between uptake of testing in firstdegree relatives and greater family support of the index case and knowledge of risk of transmission. Landsbergen et $a l^{15}$ compared the characteristics of index cases of families with a low uptake of predictive mutation tests to those of other families, finding significant relationships between low uptake and, not disclosing in person, less involvement with psychosocial workers during testing, and other variables relating to family dynamics. The authors suggest that less attention to psychosocial issues in counselling sessions may have had an inhibiting effect on the process of dissemination.

Knowledge of the recipient Little is known about the knowledge of the family member who has been informed by the proband. Denayer et $a^{22}$ assessed knowledge of CF among siblings of parents of a child with CF, finding that most had only a superficial knowledge about the inheritance of this condition. While $80 \%$ reported that the family was a source of information about CF, mentioning CF parents as information source was not significantly associated with the genetic knowledge score. Binedell 
et $a l^{33}$ found that those presenting for HD predictive testing were able to give a risk figure of $50 \%$ but had misconceptions about inheritance. Hallowell et al $^{16}$ found uncertainty about risk in women whose father had tested negative for a BRCA1/2 mutation. This is consistent with data showing that the person communicating the information may themselves have poor knowledge. ${ }^{11}$

Impact on individuals, relatives, and family relationships Study design has precluded direct assessment of the responses of family members to the risk information given by consultands, with almost all accounts provided by the consultand. ${ }^{10,18,20,21,23,24,27,28,34}$ In only one study did some of the recipients of the information directly give their reactions to researchers, indicating their dissatisfaction with the limited disclosure or secrecy of their parents and demonstrating misconceptions about their risk. ${ }^{18}$

Anticipating or actually communicating with relatives can be experienced as burdensome or difficult by the informant, ${ }^{4,8,10,13,14,26,28}$ with consultands reporting adverse reactions by some family members, often typical of responses to bad news, or a high emotional temperature. ${ }^{18,20,23,24,28}$ A list of these is provided in Table 2. Even where there were no difficulties in communication, respondents expressed concern about the quality of their relationship with their relative or spouse in the future. ${ }^{10}$ There are reports that relationships had been strengthened after disclosure. ${ }^{9,36}$

The impact on children and young adults of family communication might be expected to be different from that of adults. Carriers of BRCA $1 / 2$ mutations have reported concerns expressed by their children about their mother's future health. ${ }^{21}$ Although disclosure of BRCA1/2 results to children aged under 18 years did not relieve parental distress, ${ }^{34}$ neither did it impact on parent-child functioning. ${ }^{27}$ Indeed, some carrier mothers in another study perceived their relationship as closer after testing. ${ }^{21}$

\section{Discussion}

This review has summarised literature on process and outcome of family communication. As might be expected, communication is not uniform between or within families and the nature of interaction between informants and recipients differs. For example, a person may convey information openly and easily to some family members, but in others conversations may need to negotiate the direct refusal of the information by the family member or subtle cues that the information is unwelcome. It is therefore unsurprising that communication is, in some situations, immediate, while in others there is a delay and deliberation. This process may not be completely conscious on the part of the individual who undertakes, or is given, the task of communicating, but is evident in accounts of disclosure and nondisclosure.
It appears that communication occurs when a sense of responsibility to provide the family member with potentially important information outweighs concern about harming the individual by imparting 'bad' or potentially unwelcome news. This could be termed a 'calculus of responsibility' and demonstrates one side of the exchange of mutual obligations of trust among kin. Taking responsibility for transmitting information implies acting responsibly towards fellow family members. To act responsibly is to assess the potential consequence of sharing or withholding information and is embedded in a moral economy consisting of (mutual) assessments of competence and maturity, as exemplified by the deliberative communication strategy. Communication of genetic risk information is the result of intricate, existing ties of differing strengths.

Arguably, to genetic professionals, the potential psychosocial harm to family members is a relatively abstract concept compared to the health implications of nondisclosure. Consequently, there may be an inclination to prioritise the sharing of information over a desire to protect; reports of the experiences of genetics professionals tend to focus on overcoming problems that arise in family communication, ${ }^{38-40}$ despite recognition that these are the exception rather than the rule. ${ }^{38}$ An active approach to communication of genetic information by health professionals has been actively debated, particularly for familial hypercholesterolaemia. ${ }^{41}$ However, to date it has been rare that genetic professionals intervene directly and other means to foster the client's capacity or willingness to communicate are preferred. ${ }^{39,40}$ There are hints that this may be possible: the provision of psychosocial support is associated with greater family communication and, where emotional problems blocked the flow of information, the desire for more support was expressed retrospectively. ${ }^{15}$ While families believe that the responsibility lies with them to inform family members, they also want health professionals available in a supporting role. ${ }^{4,21}$ This seems to go beyond the simple provision of written materials. Suggestions about the way professionals may enhance family communication have been made, ${ }^{2,15,16,42}$ but this systematic review did not identify any papers evaluating in practice the ways to foster the capacity or willingness to communicate in families. Caution should be exercised when moving beyond the descriptive studies identified in this review to those testing an intervention. Rather than considering all failure to communicate as the same and testing a 'one-size-fits-all' solution, it may be more fruitful and ethical to recognise the diverse nature and causes of poor communication and address each with a distinct approach. The categorisation of Forrest et $a l^{4}$ could be particularly useful here. They suggest that declining to inform may be perceived as (1) positive - acting in order to produce benefit (such as preventing harm), (2) negative failing to act or overcome barriers, or (3) neutral perceiving that nothing is needed. Each of these categories 
Table 1 Summary of results

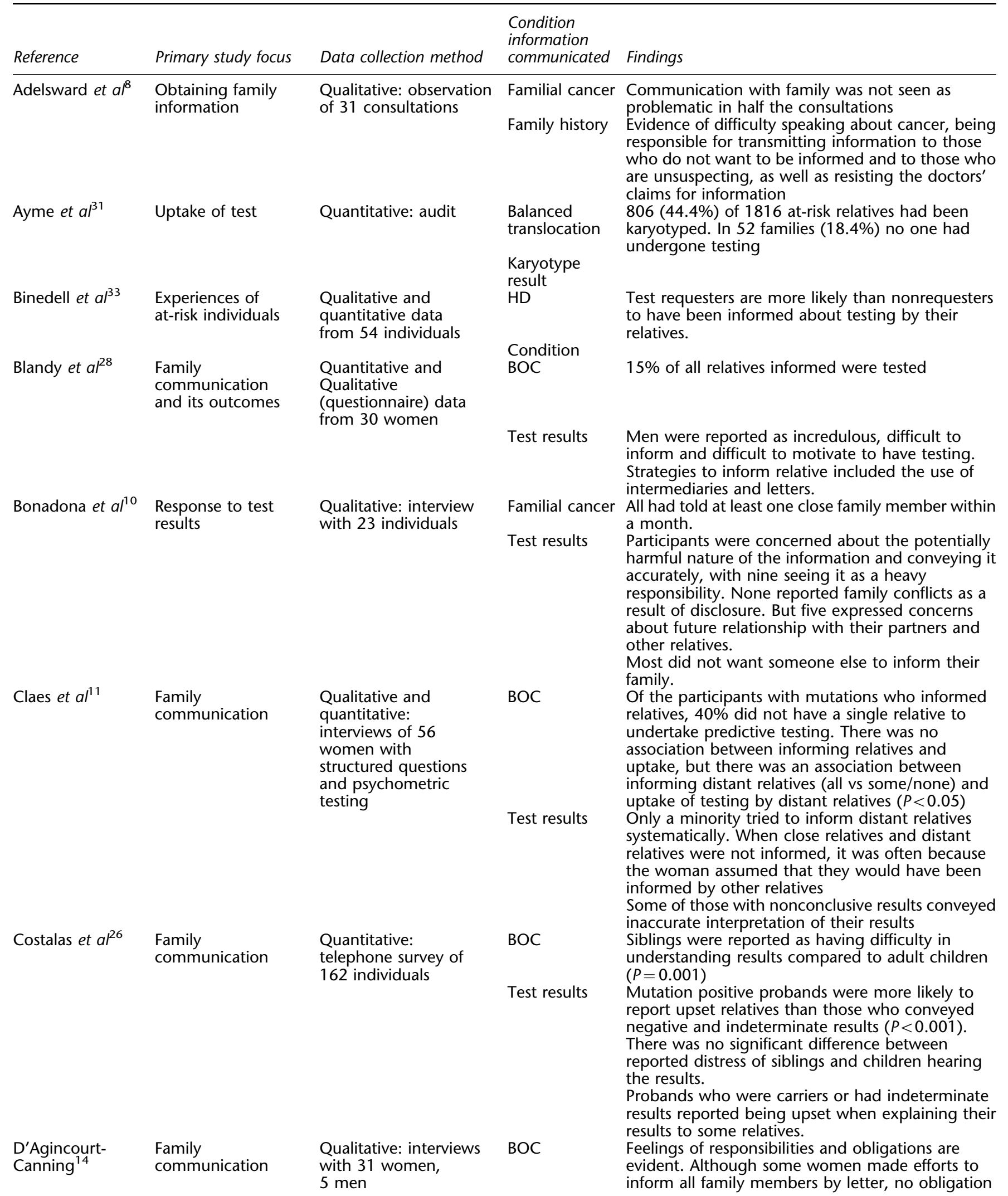


Table 1 (Continued)

\begin{tabular}{lll}
\hline & & $\begin{array}{l}\text { Condition } \\
\text { information }\end{array}$ \\
Reference $\quad$ Primary study focus Data collection method & communicated Findings
\end{tabular}

\begin{tabular}{lll}
\hline Denayer $e t a l^{22}$ & $\begin{array}{l}\text { To determine } \\
\text { relatives' awareness } \\
\text { of CF risk and how } \\
\text { it is discussed. }\end{array}$ & $\begin{array}{l}\text { Quantitative data from } \\
\text { questionnaires of } 183 \\
\text { aunts and uncles of CF } \\
\text { patients questionnaire }\end{array}$ \\
\hline
\end{tabular}

was felt to inform relatives they did not know and liaison for more distant but known family. information who, when, and how to tell; concern about causing and test results anxiety; feelings of responsibility for putting descendants at risk and fear of being blamed; family members not wanting to know

$\mathrm{CF}$ Knowledge about the risk of being a carrier or of having a child with CF was poor, with a minority able to provide this information
Genetic transmission

Qualitative data Family communication from 37 interviews

In all, $80 \%$ were informed of the hereditary nature by family, $10 \%$ had no information at all. Media was important when the family was not a source

Forrest et $a l^{4}$

Two styles of telling are described: pragmatism (active practical terms) and prevarication (looking
BOC

Genetic information and/or test results

Qualitative data

Family communication from 15 interviews
$\mathrm{BOC}$

Genetic testing for opportunities within the normal processes of family life, trying to find the right moment). The right time is often when the first key life decision affected by the disease needs to be made (eg serious relationship, marriage) or when perceived as old enough to understand.

Health professionals needed at times in supportive role

Both groups needed to make sense of their own risk (whether technically accurate or not) before dealing with whether and what to tell relatives.

Parents are seen as having the primary responsibility to hand on information to offspring. Responsibility may extend vertically (ie grandmother has more authority than an aunt, even if she is not at risk and the aunt is)

'Pivotal people' may take the responsibility for informing relatives and encouraging testing Participants experienced dilemmas balancing social role expectations and talking to relatives about genetic testing. The relative's carrier status had an impact on how and whether the women had difficulty in disclosing own results

Foster et a 9

Most women experienced barriers to communication that restricted information flow regardless of test result and some did not talk a great deal about it

They were likely to tell in person but delay informing if they were a noncarrier. This was also true if people had encouraged an affected relative to have a test and then been found not to have the mutation themselves. Disclosure could bring

relatives closer but there was concern that estranged relatives will use the information against them

The motivation for informing was usually to raise awareness of choices and predictive testing seen as good news; there was no evidence of dilemma of disclosure

Gaff et $\left.a\right|^{20}$

Family communication
Qualitative data from 12 telephone interviews
Responsibility to second- or third-degree relatives was seen as discharged by telling parents of relatives. Men sought women's assistance with disclosure. Most would not change the way they communicated 
Table 1 (Continued)

\begin{tabular}{|c|c|c|c|c|}
\hline Reference & Primary study focus & Data collection method & $\begin{array}{l}\text { Condition } \\
\text { information } \\
\text { communicated }\end{array}$ & Findings \\
\hline \multirow{2}{*}{ Green et $a l^{35}$} & \multirow{2}{*}{$\begin{array}{l}\text { Family } \\
\text { communication }\end{array}$} & \multirow{2}{*}{$\begin{array}{l}\text { Predominantly } \\
\text { Qualitative data with } \\
46 \text { preclinic and } 40 \\
\text { postclinic interviews }\end{array}$} & $\begin{array}{l}\text { Availability of } \\
\text { testing }\end{array}$ & $\begin{array}{l}\text { Family responses were reported in practical terms } \\
\text { and ranged from interest to lack of interest in } \\
\text { testing } \\
\text { The perceived usefulness of discussion about who } \\
\text { to inform was variable and gender dependent, with } \\
\text { men seeing it as more useful }\end{array}$ \\
\hline & & & $\begin{array}{l}\text { Genetic } \\
\text { information }\end{array}$ & $\begin{array}{l}\text { Approaches to family members to give information } \\
\text { were often in the context of regular social } \\
\text { contact, in order to reduce the alarm of being } \\
\text { solely contacted about the possible cancer risk }\end{array}$ \\
\hline Hallowell et $a l^{16}$ & $\begin{array}{l}\text { Family } \\
\text { communication }\end{array}$ & $\begin{array}{l}\text { Qualitative data from } \\
17 \text { interviews with } \\
\text { men, } 8 \text { spouses and } \\
4 \text { adult children }\end{array}$ & $\begin{array}{l}\text { Testing process } \\
\text { and test results }\end{array}$ & $\begin{array}{l}\text { Parents tried to balance children's rights to } \\
\text { information about their risks with parental duty not } \\
\text { to cause them any (potentially) needless anxiety, } \\
\text { resulting in different communication strategies, } \\
\text { even within one family, in response to the } \\
\text { perceived vulnerability of the daughters } \\
\text { All men deliberately managed the timing of } \\
\text { disclosure within immediate family, with it usually } \\
\text { occurring once a decision about testing had been } \\
\text { made or results were available, not during decision- } \\
\text { making period. } \\
\text { Three communication strategies were identified } \\
\text { (see text). Some regret at communication pattern } \\
\text { expressed by individuals }\end{array}$ \\
\hline Hamilton et $a P^{P}$ & $\begin{array}{l}\text { Family } \\
\text { communication }\end{array}$ & $\begin{array}{l}\text { Qualitative data from } \\
29 \text { interviews } \\
\text { (in person, by e-mail } \\
\text { or telephone) }\end{array}$ & Test results & $\begin{array}{l}\text { Differences between conditions observed with } \\
\text { respect to content and attempts to influence } \\
\text { testing decisions of relatives }\end{array}$ \\
\hline \multirow[t]{2}{*}{ Kenen et $a l^{19,23}$} & \multirow[t]{2}{*}{$\begin{array}{l}\text { Communication, } \\
\text { including family } \\
\text { communication }\end{array}$} & \multirow[t]{2}{*}{$\begin{array}{l}\text { Qualitative data } \\
\text { from } \\
21 \text { interviews }\end{array}$} & $\mathrm{BOC}$ & $\begin{array}{l}\text { Mothers were protective of their children and } \\
\text { can find it difficult to decide what and when to } \\
\text { disclose }\end{array}$ \\
\hline & & & Family history & $\begin{array}{l}\text { Mothers were only concerned about daughters and } \\
\text { granddaughters. There was variability in the } \\
\text { openness of relationship with sisters } \\
\text { Five communication strategies were identified (see } \\
\text { text) }\end{array}$ \\
\hline \multirow[t]{2}{*}{$\begin{array}{l}\text { Landsbergen } \\
\text { et } a l^{15}\end{array}$} & \multirow[t]{2}{*}{$\begin{array}{l}\text { Family } \\
\text { communication } \\
\text { and outcomes }\end{array}$} & \multirow[t]{2}{*}{$\begin{array}{l}\text { Predominantly } \\
\text { quantitative data } \\
\text { from } 50 \text { questionnaires }\end{array}$} & $\mathrm{BOC}$ & $\begin{array}{l}\text { The mean percentage of first- and second-degree } \\
\text { relatives per family not having testing was } 64 \% \\
(7-100 \%) \text {. }\end{array}$ \\
\hline & & & Test results & $\begin{array}{l}\text { Families were classified into low uptake (below } \\
20 \%) \text { and 'others'. Significant differences }(P \leq 0.05) \\
\text { in low uptake families include less presence of } \\
\text { psychosocial workers during pretest counselling; } \\
\text { retrospective desire for more support in the } \\
\text { communication with family members; parents }\end{array}$ \\
\hline
\end{tabular}


Table 1 (Continued)

\begin{tabular}{|c|c|c|c|c|}
\hline Reference & Primary study focus & Data collection method & $\begin{array}{l}\text { Condition } \\
\text { information } \\
\text { communicated }\end{array}$ & Findings \\
\hline & & & & $\begin{array}{l}\text { informed less often after disclosure and less } \\
\text { personally; and emotional problems blocking } \\
\text { dissemination }\end{array}$ \\
\hline Liede $e t a l^{36}$ & Needs evaluation & $\begin{array}{l}\text { Quantitative data from } \\
59 \text { men }\end{array}$ & $\mathrm{BOC}$ & $\begin{array}{l}\text { Five men would have liked assistance in } \\
\text { communication. }\end{array}$ \\
\hline \multirow[t]{2}{*}{ McGivern et $a l^{25}$} & $\begin{array}{l}\text { Family } \\
\text { communication }\end{array}$ & $\begin{array}{l}\text { Predominantly } \\
\text { quantitative data } \\
\text { from } 38 \text { women }\end{array}$ & $\mathrm{BOC}$ & $\begin{array}{l}\text { Parents of at-risk people who were seen as having } \\
\text { the responsibility to inform }\end{array}$ \\
\hline & & & Test results & $\begin{array}{l}\text { The content of communication included family } \\
\text { history, reasons for testing, risk of mutation, } \\
\text { feelings, insurance, cost, and surgery } \\
\text { On average, } 2.1 \text { women and } 0.6 \text { men were } \\
\text { reported as tested by each respondent. Gender } \\
\text { differences were observed }\end{array}$ \\
\hline & & & Condition & $\begin{array}{l}\text { Strategies included informing relatives alone, } \\
\text { with partner, with another family member, cascade } \\
\text { with responsibility being passed on to person told } \\
\text { (ie via relative), or no plan. 'No plan' was least } \\
\text { common and the remainder were equally } \\
\text { employed } \\
\text { Where there was no plan, then who was informed } \\
\text { was based on assumptions rather than knowledge } \\
\text { Some people found communication difficult } \\
\text { due to family responses such as shock, anger, } \\
\text { shoot the messenger; but people got used to the } \\
\text { situation overtime and learnt to cope with feelings. } \\
\text { If there was openness in family, then it was a } \\
\text { confirmation of an assumption and news spread } \\
\text { quickly and easily. Relatives were more likely then } \\
\text { to be interested in the news and sympathise with } \\
\text { messenger }\end{array}$ \\
\hline
\end{tabular}

parents of a CF child and 18 carriers of $C F$

Test results

The gender of carrier or recipient did not impact on communication patterns or uptake of screening for any group or category of relatives

Few siblings of the respondents had undergone genetic testing ( $11.5 \%$ of all siblings)

Communication was often imparted as secondary to the child's diagnosis

Parsons et $\mathrm{al}^{13} \quad$ Carrier identification Qualitative: interviews with 19 parents
CF

Test results Communication with family members was discussed in terms of obligation

Discussion with family members was seen as the most problematic consequence of newborn screening

Difficulties arose because of pregnancy, number of people, having to contact ex-partners, not enough information, and not knowing how to tell

Peterson et $a l^{17} \quad$ Family communication qualitative data from

HNPCC 29 family members and 10 spouses from 5 families
Probands wanted family to have genetic testing and believed it was important, at-risk relatives saw testing as an opportunity to gain additional information related to HNPCC than a necessity 
Table 1 (Continued)

\begin{tabular}{ll}
\hline & $\begin{array}{l}\text { Condition } \\
\text { information } \\
\text { Reference } \quad \text { Primary study focus } \quad \text { Data collection method } \\
\text { commicated }\end{array}$
\end{tabular}

Koehly et $a l^{30}$

Test results

Segal et $a 1^{21}$

Communication to offspring

Quantitative data from 31 questionnaires

BOC

Test results

Tercyak et $\left.a\right|^{34}$
Communication to children

Quantitative data from 133 adults

HBOC

BOC

Qualitative and

communication to children $(8-17$ years old) quantitative data from

42 mothers:

questionnaire with some open-ended questions
Test results The act of sharing with a child did not ameliorate

Probands and mutation carriers took the lead role in communication. Most shared with at least one first-degree relative within 2 weeks. The same pattern of communication was used as for other nonurgent family news: spouse, children and siblings first. Noncarriers perceived communication to others as less relevant and were less involved

It was considered inappropriate to discuss with nieces/nephews directly unless their parents present; the nuclear family seemed to serve as a boundary for responsibility. Dilemmas of disclosure were reported

Uptake of testing rate of $57-64 \%$ in four families within 12-14 months after disclosure

The importance of persuasion in encouraging testing was highlighted, with active and consistent persuasion needed. Family leaders in other areas did not necessarily take the lead in persuading to undergo genetic testing

The majority $(72.2 \%)$ of women disclosed to children without the involvement of a spouse

A quarter said there is a difference between disclosing to sons and to daughters, mostly due to the differences in implications for each sex. Slightly less $(22.6 \%)$ reported no difference (but two of these had only sons).

Two-thirds of carriers $(n=12)$ said their children had expressed concerns about their mother's health and their own testing. Older children tended to be more logical, want more facts, and show more concern for mother after disclosure, while younger children expressed more worries and a stronger desire for testing and prevention

None reported negative effects on relationships. Further support would have been appreciated by those who disclosed and those who did not Greater general distress was found in those who used more active or avoidant coping strategies. The authors suggest that parents' psychological distress may have played a key role in determining their communication behaviour, with those experiencing more general distress being more likely to share parental distress and few changes in distress were seen. Lazarus and Folkman's transactional theory of coping drawn on to explain findings

Mothers informed their child because of a belief they had a right to know and/or they felt a strong sense of responsibility (50\%)

Test results
Parents who did or did not disclose reported similar levels of parent-child functioning at follow-up

BOC, breast ovarian cancer; CF, cystic fibrosis; HBOC, hereditary breast ovarian cancer; HD, Huntington disease; HNPCC, hereditary nonpolyposis colorectal cancer. 
Table 2 Summary of communication difficulties

Difficulties in communication reported

Information not believed/testing rejected ${ }^{8,20,28}$

Failure or difficulty in understanding 26

Failure to convey results $4,9,13,14,20$

Speaking about cancer ${ }^{8}$

Timing $4,8,13,14,16,19$

Informing the unsuspecting ${ }^{8}$

Nonspecific 25,26

Content or knowledge 4,13,14,19,28

Emotional reactions ${ }^{24,37}$

is likely to require a different approach but distinct strategies for these different types of communication blocks were not evident in the literature.

Even with improved communication, it seems likely that there will remain relatives with whom the individual is reluctant or unable to communicate. Unwritten rules of family communication dictate who is the most appropriate person to inform certain family members. ${ }^{4,17,29,30}$ Further, family rifts are a common cause of failing to communicate. To attempt to alter existing family dynamics in an endeavour to meet the ends of the genetic services seems to be a dubious undertaking and, in the context of shortterm genetic counselling rather than family therapy, possibly unachievable. Rather than valuing the outcomes of communication identified here (eg number of family members informed, knowledge of the recipient), attention may be better focussed on the professional's exploration of existing family dynamics and communication patterns: that is, assessing the process of counselling about family communication rather than these more quantitative or focused results.

\section{Strengths and weaknesses}

The strengths and weaknesses of this review arise in two areas: the protocols used to conduct the systematic review and the nature of the literature identified. The review meets most of the AMSTAR criteria, ${ }^{43}$ although metaanalytic combination of study findings was not possible due to the heterogeneous nature of results, but study characteristics and quality are reported (summarised here and fully available in Edwards et $a l^{5}$ ). The search criteria for the overall review focussed on risk communication and also included designated-specific conditions, consequently some relevant papers may have not been identified. However, we sought to overcome this by including papers cited by those studies that were identified.

With respect to the literature reviewed, studies were predominantly on communication about hereditary cancer syndromes and, more specifically, hereditary breast cancer. Differences in communication between families with HD and those with HBOC have been described, ${ }^{4,7}$ and it may be hypothesised that family communication is influenced by the implications of the condition: the perceived treatability, perceived preventability, and reproductive implications. Similarly, communication about conditions with autosomal-dominant inheritance may not reflect communication about recessive or X-linked conditions. Therefore, conclusions drawn from data on families with familial cancer should only be extrapolated to other genetic conditions with caution.

The studies reviewed may be considered small studies and criticised for lack of representativeness. It is possible, perhaps even likely, that the results represent the views of those at the extremes of communication (very difficultvery easy). Finally, although the review intended to address 'risk communication', none of the studies framed the content of communication as solely 'risk'. It seems reasonable to cautiously assume this relationship, as one of the strongest motivations to communicate test results to family members is the desire to inform them of their risk or options, ${ }^{12,25}$ but this is certainly not the only one and communication may be used as a strategy to cope with bad news or obtain family support. ${ }^{25,32,44}$

\section{Further research}

There is a noticeable lack of examination of cultural, genetic, and gender diversity in these studies. As the implicit rules governing family communication of genetic information are likely to be dependent to an extent on cultural context, ${ }^{45}$ there is a need for studies within other cultural groups. A similar comment may be made about gender, which has been recognised as a factor affecting disclosure and nondisclosure. ${ }^{3}$ While there are hints in the literature reviewed that gender may affect the process and outcome of communication about genetic information, wider conclusions are hampered by the gender-associated nature of the conditions usually studied (ie HBOC). It would be useful to explore in more depth the experiences of men communicating about conditions such as HNPCC, $\mathrm{HD}$, and $\mathrm{CF}$, as different strategies may be more effective in assisting men to discuss genetic risk. Similarities and differences in the process of communication for genetic conditions with differing implications and inheritance patterns also need to be explored. There would also be value in considering the family communication processes that lead to an understanding of risk, which may occur over a long period of time rather than in the context of conveying a piece of information. The findings of such investigations may be relevant to communication about common complex conditions. We also propose that greater attention needs to be paid to the use of theoretical models of communication to complement empirical studies. The study of communication about genetic information needs to move beyond the simple sender-receiver model of information transfer assumed by most of the studies reviewed, which usually focus on the sender of the information. Rather, understanding needs to be developed 
about the meaning of such information to both the individuals concerned, the dynamics between them and also the influences on their relationship. Theories from the family communication literature specifically addressing information sharing within families may prove useful to inform such studies.

\section{Conclusion}

The objective of genetic services, implied by the content of research studies on family communication and guidelines in this area, ${ }^{46}$ is to maximise the flow of important information to relevant family members. But the myriad of factors that affect communication means that obligations to family members flow along channels that are not always identical with those through which genes are passed between generations: a sense of responsibility does not always map onto current biomedical models of inheritance.

Family communication is a complex process and the discussions between professional and client about dissemination of information need to recognise and respect this complexity. However, the nature of interactions about genetic information remains poorly understood. Greater attention needs to be paid to the process of communication with family members. This would inform professional discussion and possibly also the development of strategies that assist - but do not compel - clients to communicate with at-risk family members. Concurrently, desirable outcomes (beyond a one-dimensional assessment of the number of relatives informed) should be defined and include those valued by both the person communicating the information and the recipient.

\section{Acknowledgements}

We thank all members of the GENVIEW steering group, especially Rhodri Evans, Jonathon Gray, Alastair Kent, Nicholas Lench, and Melissa Winter. Particular thanks go to Engy Hussein for her administrative support throughout the project and Dr Carma Bylund for useful discussions about family communication models. This project was funded by the Department of Health in the UK (Grant HSRO3A). There are no conflicts of interest.

\section{References}

1 Parker M, Lucassen A: Concern for families and individuals in clinical genetics. J Med Ethics 2003; 29: 70-73.

2 Godard B, Hurlimann T, Letendre M, Egalite N: Guidelines for disclosing genetic information to family members: from development to use. Fam Cancer 2006; 5: 103-116.

3 Wilson BJ, Forrest K, van Teijlingen ER et al: Family communication about genetic risk: the little that is known. Community Genet 2004; 7: $15-24$.

4 Forrest $\mathrm{K}$, Simpson SA, Wilson BJ et al: To tell or not to tell: barriers and facilitators in family communication about genetic risk. Clin Genet 2003; 64: 317-326.
5 Edwards A, Sivell S, Dundon J et al: Effective risk communication in clinical genetics: a systematic review. Cardiff: Cardiff University, 2006, p 249.

6 Dixon-Woods M, Bonas S, Booth A et al: How can systematic reviews incorporate qualitative research? A critical perspective. Qualitative Res 2006; 6: 27-44.

7 Hamilton RJ, Bowers BJ, Williams JK: Disclosing genetic test results to family members. J Nurs Scholarsh 2005; 37: 18-24.

8 Adelsward V, Sachs L: The messenger's dilemmas - giving and getting information in genealogical mapping for hereditary cancer. Health Risk Soc 2003; 5: 125-138.

9 Foster C, Eeles R, Ardern-Jones A, Moynihan C, Watson M: Juggling roles and expectations: dilemmas faced by women talking to relatives about cancer and genetic testing. Psychology and Health 2004; 19: 439-455.

10 Bonadona V, Saltel P, Desseigne F et al: Cancer patients who experienced diagnostic genetic testing for cancer susceptibility: reactions and behavior after the disclosure of a positive test result. Cancer Epidemiol Biomarkers Prev 2002; 11: 97-104.

11 Claes E, Evers-Kiebooms G, Boogaerts A, Decruyenaere M, Denayer L, Legius E: Communication with close and distant relatives in the context of genetic testing for hereditary breast and ovarian cancer in cancer patients. Am J Med Genet 2003; 116A: $11-19$.

12 Hughes C, Lerman C, Schwartz $M$ et al: All in the family: evaluation of the process and content of sisters' communication about BRCA1 and BRCA2 genetic test results. Am J Med Genet 2002; 107: 143-150.

13 Parsons EP, Clarke AJ, Bradley DM: Implications of carrier identification in newborn screening for cystic fibrosis. Arch Dis Child Fetal Neonatal Ed 2003; 88: 467-471.

14 d'Agincourt-Canning L: Experiences of genetic risk: disclosure and the gendering of responsibility. Bioethics 2001; 15: 231-247.

15 Landsbergen K, Verhaak C, Kraaimaat F, Hoogerbrugge N: Genetic uptake in BRCA-mutation families is related to emotional and behavioral communication characteristics of index patients. Fam Cancer 2005; 4: 115-119.

16 Hallowell N, Ardern-Jones A, Eeles R et al: Communication about genetic testing in families of male BRCA1/2 carriers and non-carriers: patterns, priorities and problems. Clin Genet 2005; 67: 492-502.

17 Peterson SK, Watts BG, Koehly LM et al: How families communicate about HNPCC genetic testing: findings from a qualitative study. Am J Med Genet 2003; 119: 78-86.

18 Hallowell N, Ardern-Jones A, Eeles R et al: Men's decision-making about predictive BRCA1/2 testing: the role of family. I Genet Couns 2005; 14: 207-217.

19 Kenen R, Arden-Jones A, Eeles R: Healthy women from suspected hereditary breast and ovarian cancer families: the significant others in their lives. Eur J Cancer Care 2004; 13: 169-179.

20 Gaff CL, Collins V, Symes T, Halliday J: Facilitating family communication about predictive genetic testing: probands' perceptions. J Genet Couns 2005; 14: 133-140.

21 Segal J, Esplen MJ, Toner B, Baedorf S, Narod S, Butler K: An investigation of the disclosure process and support needs of BRCA1 and BRCA2 carriers. Am J Med Genet 2004; 125: 267-272.

22 Denayer L, De Boeck K, Evers-Kiebooms G, Van den Berghe H: The transfer of information about genetic transmission to brothers and sisters of parents with a CF-child. Birth Defects Orig Artic Ser 1992; 28: 149-158.

23 Kenen R, Arden-Jones A, Eeles R: We are talking, but are they listening? Communication patterns in families with a history of breast/ovarian cancer (HBOC). Psychooncology 2004; 13: 335-345.

24 Mesters I, Ausems M, Eichhorn S, Vasen H: Informing one's family about genetic testing for hereditary non-polyposis colorectal cancer (HNPCC): a retrospective exploratory study. Fam Cancer 2005; 4: 163-167.

25 McGivern B, Everett J, Yager GG, Baumiller RC, Hafertepen A, Saal HM: Family communication about positive BRCA1 and BRCA2 genetic test results. Genet Med 2004; 6: 503-509. 
26 Costalas JW, Itzen M, Malick J et al: Communication of BRCA1 and BRCA2 results to at-risk relatives: a cancer risk assessment program's experience. Am J Med Genet 2003; 119: 11-18.

27 Tercyak KP, Peshkin BN, DeMarco TA, Brogan BM, Lerman C: Parent-child factors and their effect on communicating BRCA1/2 test results to children. Patient Educ Counsel 2002; 47: $145-153$.

28 Blandy C, Chabal F, Stoppa-Lyonnet D, Julian-Reynier C: Testing participation in BRCA1/2-positive families: initiator role of index cases. Genet Test 2003; 7: 225-233.

29 Keenan KF, Simpson SA, Wilson BJ et al: 'It's their blood not mine': who's responsible for (not) telling relatives about genetic risk? Health Risk Soc 2005; 7: 209-226.

30 Koehly LM, Peterson SK, Watts BG, Kempf KK, Vernon SW, Gritz ER: A social network analysis of communication about hereditary nonpolyposis colorectal cancer genetic testing and family functioning. Cancer Epidemiol Biomarkers Prev 2003; 12: 304-313.

31 Ayme S, Macquart-Moulin G, Julian-Reynier C, Chabal F, Giraud F: Diffusion of information about genetic risk within families. Neuromuscul Disord 1993; 3: 571-574.

32 Ormond KE, Mills PL, Lester LA, Ross LF: Effect of family history on disclosure patterns of cystic fibrosis carrier status. Am J Med Genet C Semin Med Genet 2003; 119: 70-77.

33 Binedell J, Soldan JR, Harper PS: Predictive testing for Huntington's disease: II. Qualitative findings from a study of uptake in South Wales. Clin Genet 1998; 54: 489-496.

34 Tercyak KP, Hughes C, Main D et al: Parental communication of BRCA1/2 genetic test results to children. Patient Educat Counsel 2001; 42: 213-224.

35 Green J, Richards M, Murton F, Statham H, Hallowell N: Family communication and genetic counseling: the case of hereditary breast and ovarian cancer. J Genet Counsel 1997; 6: 45-60.

36 Liede A, Metcalfe K, Hanna D et al: Evaluation of the needs of male carriers of mutations in BRCA1 or BRCA2 who have undergone genetic counseling. Am I Hum Genet 2000; 67: 1494-1504.

37 Lim J, Macluran M, Price M, Bennett B, Butow P: Short- and longterm impact of receiving genetic mutation results in women at increased risk for hereditary breast cancer. J Genet Couns 2004; 13: $115-133$.

38 Clarke A, Richards M, Kerzin-Storrar L et al: Genetic professionals' reports of nondisclosure of genetic risk information within families. Eur J Hum Genet 2005; 13: 556-562.

39 Dugan RB, Wiesner GL, Juengst ET, O'Riordan M, Matthews AL, Robin NH: Duty to warn at-risk relatives for genetic disease: genetic counselors' clinical experience. Am J Med Genet 2003; 119C: $27-34$.

40 Falk MJ, Dugan RB, O'Riordan MA, Matthews AL, Robin NH: Medical geneticists' duty to warn at-risk relatives for genetic disease. Am J Med Genet 2003; 120: 374-380.

41 Newson AJ, Humphries SE: Cascade testing in familial hypercholesterolaemia: how should family members be contacted? Eur Hum Genet 2005; 13: 401-408.

42 Daly M, Barsevick A, Miller S et al: Communicating genetis test results to the family: a six step, skills building strategy. Fam Community Health 2001; 24: 13-26.

43 AMSTAR. Proposed Evaluation Tools for COMPUS: https:// www.ccohta.ca/compus/compus_pdfs/COMPUS_Evaluation_ Methodology_draft_e.pdf, Ottawa: Canadian Coordinating Office for Health Technology Assessment, 2005.

44 Lerman C, Peshkin B, Hughes C, Isaacs C: Family disclosure in genetic testing for cancer susceptibility: determinants and consequences. J Health Care Law Policy 1998; 1: 353-372.

45 Strathern M: The work of culture: an anthropological perspective In Clarke A, Parsons E (eds).: Culture, Kindship \& Genes: Towards Cross-Cultural Genetics. Basingstoke: McMillan press, 1997.

46 Forrest L, Delatycki M, Skene L, Aitken M: Communicating genetic information in families - a review of guidelines and position papers. Eur J Human Genet 2007; 15: 612-618.

Supplementary Information accompanies the paper on European Journal of Human Genetics website (http://www.nature.com/ejhg) 